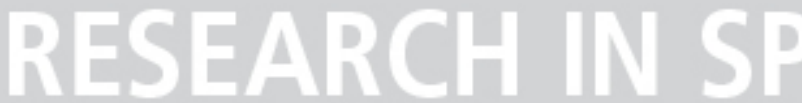 \\ PHYSICAL A TIN
}

2 adrenergic regulation of the phagocytic activity of monocytes in obese mice: effect of an acute intense exercise

Autor(es): $\quad$ Martín-Cordero, L; Gálvez, I; Álvarez-Barrientos, A; Ortega, E

Publicado por: Imprensa da Universidade de Coimbra

URL persistente:

URI:http://hdl.handle.net/10316.2/44160

DOI:

DOI:https://doi.org/10.14195/2182-7087_ex2018_97

Accessed : $\quad$ 26-Apr-2023 10:58:19

A navegação consulta e descarregamento dos títulos inseridos nas Bibliotecas Digitais UC Digitalis, UC Pombalina e UC Impactum, pressupõem a aceitação plena e sem reservas dos Termos e Condições de Uso destas Bibliotecas Digitais, disponíveis em https://digitalis.uc.pt/pt-pt/termos.

Conforme exposto nos referidos Termos e Condições de Uso, o descarregamento de títulos de acesso restrito requer uma licença válida de autorização devendo o utilizador aceder ao(s) documento(s) a partir de um endereço de IP da instituição detentora da supramencionada licença.

Ao utilizador é apenas permitido o descarregamento para uso pessoal, pelo que o emprego do(s) título(s) descarregado(s) para outro fim, designadamente comercial, carece de autorização do respetivo autor ou editor da obra.

$\mathrm{Na}$ medida em que todas as obras da UC Digitalis se encontram protegidas pelo Código do Direito de Autor e Direitos Conexos e demais legislação aplicável, toda a cópia, parcial ou total, deste documento, nos casos em que é legalmente admitida, deverá conter ou fazer-se acompanhar por este aviso. 


\section{ANNALS OF RESEARCH IN SPORT AND PHYSICAL ACTIVITY}




\title{
B2 ADRENERGIC REGULATION OF THE PHAGO- CYTIC ACTIVITY OF MONOCYTES IN OBESE MICE: EFFECT OF AN ACUTE INTENSE EXERCISE
}

\author{
Martín-Cordero L1; Gálvez I; Álvarez-Barrientos A33; Ortega E²
}

KEYWORDS: acute exercise, adrenergic receptor, obesity, phagocytosis

Obesity is a worldwide epidemic and it is associated with comorbid conditions that involve alterations of the innate/inflammatory immune response. Obesity is also correlated with changes in the activity of the sympathetic nervous system (SNS) and the hypothalamicpituitary-adrenal (HPA) axis. Catecholamines are important immunoregulatory molecules, and adrenergic agonists interfere with the inflammatory response. On the other hand, physical activity, besides activating the SNS and HPA axis, is an event that can reverse pathologies arising from obesity ${ }^{(1)}$. However, the influence of obesity on the adrenergic regulation of the immune system, and the influence of exercise on the mechanisms underlying this regulation in obesity, is still not well understood. The aim of this study was to investigate the influence of obesity and the effects of a single bout of acute exercise (running, 35 min at $16 \mathrm{~m} / \mathrm{min}$ ) on the $\beta_{2}$ adrenergic regulation of the phagocytic capacity of monocytes. A group of 20 ten-week old C57BL/6J mice were fed a diet containing either 5\% (lean group, $n=10$ ) or $40 \%$ of fat $-60 \%$ of the kcal from fat- (obese group, $n=10$ ) for 18 weeks. Then, 5 animals from each group were subjected to the acute exercise. The monocytes' phagocytic capacity was evaluated by flow cytometry in whole blood collected by cardiac puncture, in the presence or absence of the $\beta_{2}$ adrenergic agonist terbutaline. First, obese mice showed a lower phagocytic monocyte percentage than lean mice, and the acute exercise decreased the phagocytic monocyte percentage (mainly in lean mice) and increased their phagocytic activity in both groups. Terbutaline decreased the phagocytic percentage in both lean and obese mice, but it did not change the phagocytic activity. However, animals that performed

\footnotetext{
1 Immunophysiology Research Group, Department of Nursing, University of Extremadura, Spain.

2 Immunophysiology Research Group, Department of Physiology, University of Extremadura, Spain;

3 Facility of Bioscience Applied Techniques, University of Extremadura, Badajoz, Spain.

Email: orincon@unex.es; leticiamartin@unex.es; igalvez@unex.es
} 
the bout of acute exercise (both lean and obese), presented an increased phagocytic activity in response to terbutaline. To conclude, it seems that, although there was an overall lower phagocytic capacity of monocytes in obesity, both obese and lean mice showed a similar response to acute exercise and a similar $\beta_{2}$ adrenergic regulation of phagocytosis. However, this $\beta_{2}$ adrenergic regulation seemed to be different after acute exercise than at rest, since the $\beta_{2}$ adrenergic stimulation induced an increased phagocytic activity only during acute exercise.

This investigation has been supported by "Ministerio de Economía y Competitividad" (DEP2015-66093-R). We would like to thank the STAB (UEx) for technical and human support.

\section{REFERENCES}

1. Ortega, E., Martín-Cordero, L., García-Roves, P.M., Chicco, A.J., González-Franquesa, A., Marado, D. (2015). Diabetes Mellitus and Metabolic Syndrome. In: Palavra, F., Reis, F., Marado, D., Sena, A. ed. Biomarkers of Cardiometabolic Risk, Inflammation and Disease. Switzerland: Springer International Publishing, pp. 55-79. 